\title{
Woodrow Wilson and Wilsonianism a Century Later
}

Lloyd E. Ambrosius

Historians and political scientists have agreed that President Woodrow Wilson sought to create a new world order of liberal internationalism during the peacemaking after World War I, but that he failed in this mission. We have identified his global vision with the Anglo-American political tradition of liberalism, viewing him as its preeminent advocate. We have also generally acknowledged that his legacy of Wilsonianism continued to influence U.S. foreign policy and, consequently, world history for the next century. Beyond this consensus, however, we have disagreed. Scholars who have studied Wilson and his role in international politics have given various reasons for his failed presidential leadership. Some blamed him and the inherent limits of his ideas. Others criticized the Europeans for adhering to the old diplomacy of military alliances and a balance of power in international relations or suggested that Wilson's vision of a new world order was too far ahead of its time. We have also given various interpretations of his ideas for global reform after World War I and, even more, of whether later generations adhered to his legacy or deviated from it with their own questionable definitions of Wilsonianism.

Historian Timothy Snyder, in The Road to Unfreedom (2018), offered a framework for understanding the history of the twentieth and twenty-first centuries that will help to reevaluate Wilson and Wilsonianism. He observed that two kinds of politics competed against each other, neither of which has provided an authentic history. One is the politics of inevitability; the other is the politics of eternity. He explained, "Americans and Europeans were guided through the new century by a tale about 'the end of history,' by what I will call the politics of inevitability, a sense that the future is just more of the present, that the laws of progress are known, that there 
are no alternatives, and therefore nothing really to be done. In the American capitalist version of this story, nature brought the market, which brought democracy, which brought happiness. In the European version, history brought the nation, which learned from war that peace was good, and hence chose integration and prosperity." History, however, moved in different directions, increasingly leaving some in Europe and then the United States to adopt the alternative. "The collapse of the politics of inevitability ushers in another experience of time: the politics of eternity," Snyder observed. "Whereas inevitability promises a better future for everyone, eternity places one nation at the center of a cyclical story of victimhood. Time is no longer a line into the future, but a circle that endlessly returns to the same threats from the past. Within inevitability, no one is responsible because we all know that the details will sort themselves out for the better; within eternity, no one is responsible because we all know that the enemy is coming no matter what we do. Eternity politicians spread the conviction that government cannot aid society as a whole, but can only guard against threats. Progress gives way to doom."1 Both of these kinds of politics affirmed and depended on the acceptance of false understandings of history.

Snyder encouraged us to reject both the politics of inevitability and the politics of eternity in favor of the politics of responsibility. In place of their false narratives, we should confront our history. "Inevitability and eternity translate facts into narratives," he observed. "Those swayed by inevitability see every fact as a blip that does not alter the overall story of progress; those who shift to eternity classify every new event as just one more instance of a timeless threat. Each masquerades as history; each does away with history. Inevitability politicians teach that the specifics of the past are irrelevant, since anything that happens is just grist for the mill of progress. Eternity politicians leap from one moment to another, over decades or centuries, to 
build a myth of innocence and danger. They imagine cycles of threat in the past, creating an imagined pattern that they realize in the present by producing artificial crises and daily drama." Snyder warned that the study of history is not easy but is essential to escape the false narratives of inevitability and eternity. "To think historically is to accept that the unfamiliar might be significant, and to work to make the unfamiliar the familiar." He explained, "The only thing that stands between inevitability and eternity is history, as considered and lived by individuals. If we grasp eternity and inevitability as ideas within our own history, we might see what has happened to us and what we might do about it.... The virtue of individualism becomes viable in the throes of our moment, but it will abide only if we see history and ourselves within it, and accept our share of responsibility." For Snyder, responsible individuals need to create their own history, which is essential to freedom. "To think historically is to see the limits of structures, the spaces of indeterminacy, the possibilities for freedom." He concluded, "If we see history as it is, we see our places in it, what we might change, and what we might do better. We halt our thoughtless journey from inevitability to eternity, and exit the road to unfreedom. We begin a politics of responsibility."2

In substantial agreement with Snyder, political scientist John J. Mearsheimer contrasted "liberal dreams and international realities" in The Great Delusion (2018). He analyzed how liberalism, nationalism, and realism have interacted to influence international relations. $\mathrm{He}$ viewed political scientist Francis Fukuyama's idea of the "end of history" as a prime example of America's progressive liberalism in the post-Cold War era. ${ }^{3}$ Both Snyder and Mearsheimer saw this interpretation as deeply flawed and dangerous. In The End of History and the Last Man (1992), Fukuyama asserted that the end of the Cold War and the collapse of the Soviet Union marked the global triumph of liberal democracy and capitalism. The West, and particularly the 
United States, had won. Wilson's vision of a new world order had been fulfilled, marking the culmination of what Snyder would call the politics of inevitability and Mearsheimer would describe as America's pursuit of liberal hegemony. Fukuyama affirmed that "the fact that there will be setbacks and disappointments in the process of democratization, or that not every market economy will prosper, should not detract us from the larger pattern that is emerging in world history." He claimed that the "choices that countries face in determining how they will organize themselves politically and economically [have] been diminishing over time." Although history had witnessed various regimes in the past, he rejoiced that "the only form of government that has survived intact to the end of the twentieth century has been liberal democracy." ${ }^{\text {In }}$ In other words, the progressive Wilsonian promise had been realized. Liberalism had inevitably triumphed in world history.

Mearsheimer argued, in opposition to Fukuyama, that realism offered a much better guide to international relations than liberalism. Although he affirmed liberal values within the United States and other nations, he warned against the temptation of leaders in liberal democratic states to seek to impose their own presumably universal norms on other countries, by military force if necessary. "The principal source of the problem," he observed, "is that liberalism has an activist mentality woven into its core. The belief that all humans have a set of inalienable rights, and that protecting these rights should override other concerns, creates a powerful incentive for liberal states to intervene when other countries-as they do on a regular basis-violate their citizens' rights. ... This logic pushes liberal states to favor using force to turn autocracies into liberal democracies, not only because doing so would ensure that individual rights are never again trampled in those countries, but also because they believe liberal democracies never fight wars with each other." Instead of protecting universal human rights and promoting democratic 
governance, Mearsheimer noted, liberal interventions during the post-Cold War era resulted in illiberal outcomes and produced more wars, not perpetual peace. This use of military force, rather than making the world more democratic, jeopardized freedom and civil rights in the United States. It failed both abroad and at home. "In short," he concluded, "liberalism is a fool's guide for powerful states operating on the world stage. It would make eminently good sense for the United States to abandon liberal hegemony, which has served it so poorly, and pursue a more restrained policy abroad. In practice that means American policymakers should embrace realism." 5

Political scientist Stephen M. Walt made a similar critique of America's post-Cold War "liberal hegemony" in The Hell of Good Intentions (2018). Despite the liberal promise or the "evangelical impulse" in U.S. foreign policy from Wilson's call to make the world "safe for democracy" to Fukuyama's idea of the "end of history," he noted, "efforts to spread U.S. values have not been nearly as effective as its proponents maintain. If anything, overzealous efforts to export America's ideals have unwittingly subverted them at home and abroad, and the exuberant faith in the superiority of American institutions that prevailed at the end of the Cold War had given way to dark doubts about these same institutions by 2016." ${ }^{6}$ In other words, the false promise of the politics of inevitability helped usher in the politics of eternity.

As a realist, Mearsheimer emphasized the importance of focusing on the balance of power in international politics. He observed that all states seek to ensure their survival by gaining and preserving their relative power in the world. Along with other liberal democracies, the United States operates in this realistic way despite its leaders' use of liberal rhetoric to justify their behavior. In The Tragedy of Great Power Politics (2001), Mearsheimer had examined the history of international relations from the end of the eighteenth century to the beginning of the 
twenty-first, focusing on the great powers because they were the dominant actors in the anarchic world of international politics. The tragic reality was that states were prone to start wars when they expected to improve their status. He observed, "It is not even the case that there is at least one type of political system or culture-including democracy-that routinely eschews aggression and works instead to defend the status quo."7 Thus realism, not liberalism, has characterized international politics.

Mearsheimer acknowledged his indebtedness to other realists, notably historian E. H. Carr and political scientists Hans Morgenthau and Kenneth Waltz. He noted differences among the realists, although all of them recognized the importance of a balance of power among states, the principal actors in international relations. Like other realists, he understood the propensity of American leaders, certainly including Wilson, to denigrate power politics and instead proclaim liberal ideals. "Even important realist thinkers such as Norman Graebner, George Kennan, and Walter Lippmann believe that the United States has frequently ignored the imperatives of power politics and instead acted in accordance with idealist values." Such an approach, Mearsheimer emphasized, offered a false promise. "The optimists' claim that security competition and war among the great powers has been burned out of the system is wrong. In fact, all of the major states around the globe still care deeply about the balance of power and are destined to compete for power among themselves for the foreseeable future. Consequently, realism will offer the most powerful explanations of international politics over the next century, and this will be true even if the debates among academic and policy elites are dominated by non-realist theories. In short, the real world remains a realist world." $"$

Advocates of non-realist theories, including especially political scientists but also some historians, who have affirmed various versions of Wilsonianism after the Cold War, have often 
rejected realism by falsely identifying it with their own distorted interpretations of it. Kenneth Waltz contributed to this misunderstanding. His realist theory of international politics stated that states are unitary and rational actors that seek to maximize their own power. Their practices are frequently amoral or immoral. Although he gave this definition of realism as a description of the pursuit of power in international politics, non-realist scholars often construed it as an affirmation of realists' normative values. They filtered his definition through their own liberal lens, which highlighted the ideals of a new world order instead of the historical reality. It was a fairly good description of Secretary of State Henry Kissinger's diplomacy and values, but unlike him most realists never advocated amoral or immoral statecraft like he practiced. Unlike him, classical realists such as theologian Reinhold Niebuhr, journalist Walter Lippmann, diplomat-historian George F. Kennan, and political scientist Hans J. Morgenthau did not worship power, although they emphasized its centrality in international politics. Not devoid of ethics, their versions of realism were substantially different from the characterization of it by more recent non-realist theorists. ${ }^{9}$

Political scientists and historians who have criticized realism in recent years have all too often overlooked its ethical foundation. They would probably be surprised to know that during the post-World War II occupation of Japan, Norman A. Graebner taught educational courses on American democracy to Japanese adults at their request. He clearly understood the values of liberal democracy. In this way, he was promoting democracy abroad. But as a realist historian, he recognized the importance of restraint in seeking to impose it on other countries by military force. ${ }^{10}$ As one of Graebner's students, I owe much to him and classical realists. The distortion of the definition of realism by non-realist theorists has enabled them to reaffirm the Wilsonian legacy of liberal internationalism without directly confronting the realist critique by him or 
others, including myself. ${ }^{11}$ I have benefited from what I learned from classical realists, and especially from Graebner, yet my interpretations of Wilson and Wilsonianism differ from theirs in fundamental ways. Earlier than most realists as well as other scholars, I emphasized the profound influence of Wilson's Christian religion and his white racism on his worldview and, consequently, on his diplomacy. Fortunately, historians and political scientists have increasingly recognized these religious and racial factors in the president's foreign policy and legacy. ${ }^{12}$ More than most political scientists, Tony Smith has examined in depth Wilson's ideas and statecraft and his legacy of Wilsonianism. He offered mostly favorable interpretations of the president and of his enduring vision of a new world order. In America's Mission (1994), Smith rejoiced that by the end of the Cold War there was a bipartisan consensus in the United States regarding "the essential tenets of liberal democratic internationalism, or what might be called Wilsonianism: the conviction that American national interests could best be pursued by promoting democracy worldwide." He explored "the origins and the consequences of the central ambition of American foreign policy during the twentieth century: in Woodrow Wilson's words, 'to make the world safe for democracy."' Smith thought that the United States, by pursuing this mission, had played a major role in shaping international history. He criticized realism, which he regarded as "the dominant school of international relations theory," for underestimating the contribution to America's national interests from its promotion of liberal internationalism in the world. Yet he affirmed the realist emphasis on restraint in the use of military force, wanting to combine this prudent advice with the Wilsonian approach to international relations. "Liberal democratic internationalists should understand that democracy cannot be foisted on a world that is unready for it, just as realists should grasp that the Wilsonian effort to provide stable, modern, democratic government to foreign peoples may well serve American security." He cautioned 
against either excessive optimism or excessive pessimism about the Wilsonian promise of a new world order. "Given the vital American security interests served by the expansion of democracy worldwide, Wilsonianism will continue to serve as a principal guide for policy. Yet given the established character of other peoples and the obvious limits on American power, Wilsonianism will not everywhere be a relevant framework for action." ${ }^{\text {13 }}$ Unlike Francis Fukuyama, Smith did not believe that the world had reached the "end of history," but he nevertheless thought it was moving progressively in the right direction, thanks to the Wilsonian legacy in U.S. foreign policy.

What Smith heralded as the American promise of liberal democratic internationalism during the 1990s turned into Washington's bid for world supremacy after 9/11. He regretted his contribution to this betrayal of Wilson's legacy. The bipartisan consensus in favor of protecting human rights and promoting democracy abroad, which he had touted, provided some intellectual legitimacy for the Bush Doctrine, which justified America's military intervention in Iraq in 2003. Combining the rhetoric of neoliberals with the agenda of neoconservatives, President George W. Bush won their support for his imperial war. He transformed Wilsonianism into a bid for global hegemony. "The definition of megalomania well suits the Bush Doctrine," Smith lamented. "Its delusion of omnipotence rested on its belief that America enjoyed both military primacy and a blueprint for world order thanks to its global experiences fostering 'free market democracies.' ... And because a brutal war was launched on the terms of this doctrine, a conflict that has benefited no one involved in it and is far from ended, the stated grounds for war have shown themselves to be pathological as well." ${ }^{14}$ Smith had not anticipated his own complicity in this transformation of Wilsonianism.

Contrary to the realists' advice, Bush's Iraq war of "liberal imperialism" required the 
abandonment of restraint in the use of military force. He was aided by liberals who had justified military intervention to protect human rights and promote democracy abroad. "Realism, then, was the opponent the liberals of the 1990s set out to slay." Non-realist theorists succeeded at that task, at least in their own judgment, but with what Smith saw as a tragic end for Wilson's legacy. Consequently, "A progressive ideology born of an anti-imperialist concern to spread liberal democracy so as to enhance the prospects of 'perpetual peace' had joined forces with an imperialist enterprise that made perpetual war more likely. Just as fascism and communism had met their historical limits, so now too has liberal democratic internationalism.” Becoming prowar hawks, many liberals made, as Smith described in his book, A Pact with the Devil (2007). ${ }^{15}$ Or, as Timothy Snyder would later explain, progressive advocates of the politics of inevitability facilitated the transition to the politics of eternity. By offering a false Wilsonian promise to make the world safe for democracy, they actually helped move the United States down the road to unfreedom. Wilson had done the same thing during World War I. While promising to save Western civilization and liberal democracy, he sought political unity at home by repressing the civil liberties of dissenters, coercing American citizens in other ways to support the war, and denying racial democracy to African Americans. His illiberal politics culminated in the postwar Red Scare. ${ }^{16}$

Despite the tragic outcome of Bush's war and the resulting crisis of liberal democratic internationalism, Smith did not lose his faith in Wilsonianism as he defined it. In Why Wilson Matters (2017), he called for the restoration of "liberal realism" or "realistic liberalism" in U.S. foreign policy. He echoed the plea of Francis Fukuyama, who had belatedly acknowledged the folly of the Bush Doctrine and suggested, "What we need, in other words, is a more realistic Wilsonianism that matches means to ends in dealing with other societies." ${ }^{17}$ Smith wanted to 
revive what he called "Wilson's Wilsonianism." He downplayed the influence of the president's Christian religion on his global mission, which Smith saw as far less of a moral crusade than neo-Wilsonianism of the recent past. It was far more prudent in practice. He recognized that Wilson favored "progressive imperialism" through the use of military force to fulfill the White Man's Burden but saw it as more benign than Bush's "liberal imperialism." "The problem with the neo-Wilsonians," Smith argued, "was that they had taken on a universal mission that knew no boundaries. Lacking restraint, their self-righteous imperialism had launched a clash of civilizations, whose eventual intensity they then attributed not to their own actions but to the character of their adversaries, whose opposition to liberal values and institutions only served to strengthen their conviction that pushing the liberal agenda was the only way to move forward." In Smith's view, Wilson did not make that mistake. "Like the neo-Wilsonians, Wilson was an idealist whose sense of history led him to work for progressive change. But unlike his intellectual great-grandchildren, he was a realist as well, for he had learned from history, and his own efforts to influence it, of the difficulties inherent in democratic nation- and state-building." 18 Thus Smith sought to revive Wilson's liberal internationalism.

Four distinguished scholars, including Smith, analyzed Wilsonianism in the twenty-first century at the end of Bush's presidency. In The Crisis of American Foreign Policy (2009), they disagreed about whether his failure resulted from adherence to or departure from the Wilsonian tradition and also about its true character. In the introduction to the volume, political scientist G. John Ikenberry noted that "Woodrow Wilson's vision embodied impulses toward both 'liberal internationalism' and 'liberal imperialism' (or 'liberal interventionism'), an awkward and problematic duality that persists today within the liberal tradition." Thus, he observed, "the debate is not simply the question of whether Bush is a Wilsonian-it is about the future of liberal 
internationalism." ${ }^{19}$ Believing it did have a future, if correctly understood, Ikenberry would give a more complete answer in Liberal Leviathan (2011). He explained that President Franklin D. Roosevelt had updated Wilson's vision, thereby enabling the United States to become a global hegemon after World War II. "Defined in terms of the provision of security, wealth creation, and social advancement, this liberal hegemonic order has been, arguably at least, the most successful order in world history." "Like Wilson's version," he added, "it would be a one-world system in which the major powers would cooperate to enforce the peace. ... The ultimate outcome was more Western-centered, multilayered, and deeply institutionalized than originally anticipated, and it brought the United States into direct political and economic management of the system. ... The updated Wilsonian vision of liberal order turned into true liberal hegemonic order." 20

As Ikenberry had argued in After Victory (2001), this new world order after World War II depended on adding realism to liberalism. In this comparative study of peacemaking in 1815 , 1919, 1945, and 1989, he emphasized the importance of both traditions in international politics. Enduring peace required a postwar strategic balance among the victorious and defeated great powers. Unfortunately, Wilson's peacemaking after World War I, eschewing a balance of power and military alliances, contrasted negatively with the more successful diplomacy after the Napoleonic Wars, World War II, and the Cold War. Ikenberry attributed the president's failure to his lack of realism. By avoiding this error, later generations of American policymakers, along with Europeans, were able to create a peaceful world order of liberal internationalism. ${ }^{21}$

Historian Thomas J. Knock, in his chapter, did not think that Wilson's successors in the White House implemented his liberal vision of a new world order in any way. While Ikenberry saw Bush's foreign policy after 9/11 as the negative side of Wilsonianism, Knock regarded the 
conservative Bush as not at all like the progressive Wilson. In To End All Wars (1992), he had argued that the president originated his vision of "progressive internationalism" during World War I, creating a broad coalition of liberals and socialists to support it. "The ultimate objective of Wilson and the progressive internationalists was a lasting peace that would accommodate change and advance democratic institutions and social and economic justice; and a just peace was dependent on the synchronous proliferation of political democracy and social and economic justice around the world." 22 The president succeeded at the Paris Peace Conference of 1919 in writing his vision into the Covenant for the League of Nations, but he failed to secure the U.S. Senate's approval of the Versailles Treaty that included it. Wilson's quest for a new world order thus ended without an enduring legacy. Knock identified Wilsonianism with multilateralism, which contrasted with Bush's unilateralism and imperialism. In the current crisis of American foreign policy, he saw the advice of Robert S. McNamera and James Blight in Wilson's Ghost (2001) as the way to construct an authentic Wilsonian legacy. The former secretary of defense and the political scientist also emphasized multilateralism. They thought Wilson's ghost-like Jacob Marley's in Charles Dickens's A Christmas Carol -was calling out to them with a message for reducing the risk of conflict, killing, and catastrophe in the twenty-first century. Rather than being wary of anyone who was seeing ghosts, Knock welcomed their advice for a new world order. "With respect to disarmament, peacekeeping, and conflict resolution, Wilson's Ghost remains the only study of its kind, to date, devoted exclusively to exploring the relevance of authentic Wilsonian internationalism for the twenty-first century." He recommended the revival of "what one might call 'Wilsonian Wilsonianism.",23

Unlike Knock, Smith emphasized similarities between Bush's and Wilson's foreign policies. In his chapter, he blamed contemporary Wilsonians for contributing to the Bush 
Doctrine, which justified American imperialism in the Middle East. Liberal internationalists, like himself, had helped lay the intellectual foundation for Bush's conservative foreign policy. He coopted their liberal ideas of democratic peace theory and humanitarian intervention in his rationale for the global war on terrorism after 9/11. "Here was the quintessential expression of the Wilsonian dream: that war could be replaced by peace if the peoples of the world came to agreement on how rightly to govern themselves." Unfortunately, however, the Iraq war's tragic consequences discredited Wilsonianism. "Because many leading Democratic intellectuals became as committed to the invasion of Iraq as the neoconservatives ever were, the antiwar movement has been weak and the appeal of the kind of thinking one finds in the Bush Doctrine seems likely to endure. Viewed from this perspective, Wilsonianism is in crisis-the dimension of the defeat in Iraq makes any other conclusion impossible to sustain. Yet given its resonance with American interests and values, its tenets may well endure in modified form to guide this country in world affairs." 24

Political scientist Anne-Marie Slaughter sharply disagreed with Smith, denouncing him for apparently losing his faith in Wilsonianism. In her chapter, she charged that he incorrectly interpreted and thus falsely blamed Wilson's legacy for contributing to Bush's foreign policy. "In fact," she asserted, "liberal internationalism today, true to its Wilsonian origins, differs from the Bush Doctrine on multiple dimensions." Still looking forward to "a genuinely Wilsonian moment," she remained hopeful about finding liberal democratic solutions for the problems in international politics. "Wilsonianism, properly adapted and updated, offers a far better guide to meeting these challenges in the twenty-first century." She contrasted Wilson's multilateralism with Bush's unilateralism. She also defended democratic peace theorists and advocates of humanitarian intervention, denying that they were at all responsible for Bush's Iraq war. A 
liberal hawk herself, Slaughter admitted some errors in judgment. "Smith is right to say that many strong supporters of the responsibility to protect, including me, saw Saddam Hussein through the lens of his horrific human rights violations, a view that in turn may have led us to be more willing to believe that he had nuclear or biological weapons without carefully scrutinizing the available evidence. We were wrong." Slaughter had succumbed to the temptation that John Mearsheimer identified at the core of liberalism. Yet she insisted that liberal internationalists, like herself, who adhered to the Wilsonian tradition, were not responsible for contributing to Bush's military crusade in the Middle East. "Liberal internationalists do believe in American leadership, but not in supremacy or hegemony." She concluded, "We must find ways to work together to achieve Wilson's vision: a world made safe for democracy, prosperity, knowledge, beauty, and human flourishing."25

Historian Trygve Throntveit offered a unique perspective on America's internationalist experiment after World War I in Power Without Victory (2017). He claimed that "Wilson was not a 'Wilsonian,' as that term has come to be understood. He did not seek to stamp Americanstyle democracy on other peoples. Rather, he had something simultaneously more radical and more practical in mind: the gradual development of a global system of governance to maintain justice and facilitate peaceful change." Rejecting realism as a false interpretation of or guide to international relations, Throntveit argued that Wilson derived his plan for the League of Nations from American pragmatism. Even liberal internationalists who supported him often failed to grasp his vision of "the possibility of a supranational authority bringing order to the interstate system" to overcome international anarchy. "Wilson's pragmatist League was never tested; we know only that a very different League did fail and that its very different successor is gravely impaired by the recalcitrance of its strongest members." What later generations called 
Wilsonianism did not match his radical, yet practical, vision for a new world order. Throntveit traced Wilson's ideas to the philosopher Henry James, whose pragmatism influenced liberal progressives in the early twentieth century. A pragmatic style of politics allowed for historical contingency. Thus, he noted, "true democracy, as James understood it, implies a contingent kind of progress, its standards subject to revision and achieved through trial and error." Pragmatists in the James tradition applied this insight to international relations during World War I. In Wilson's words, both domestic and international politics required "common counsel" to achieve progress. "More than anything except the events of the Great War itself," Throntveit observed, "this strain of pragmatist internationalism determined the course of Wilson's presidency, dovetailing with his domestic thinking, clarifying the lessons of his early diplomacy, and providing both a theoretical underpinning and an influential constituency to support his own burgeoning internationalism."26

Throntveit recognized that Wilson failed to create his new world order after World War I, yet he still believed the president had promoted the right vision. "This was the contribution of the pragmatist progressives to twentieth-century internationalism: the notion that the old model of sovereignty was deadly inefficient, and even uncertain experiments in pooling sovereignty were preferable." The key to overcoming the dangers of nationalism was a new diplomacy of international common counsel. "Throughout 1918," Throntveit explained, "Wilson and his close advisers expanded the Fourteen Points into a pragmatist program for global governance, one just radical enough to be practical-or at least to seem so to tens of millions worldwide who had borne the burden of nationalist rivalry and political opposition far too long." This would require the partial surrender of national sovereignty. "The integrity of the League, and the future peace of the United States, demanded that the country's government and people respect the common 
counsel of the world." Unfortunately, in Throntveit's view, Wilson did not practice this kind of diplomacy during the peacemaking in 1919. Even more, he took an "absolutist turn" at home, telling the Senate that the Versailles Treaty with the League Covenant expressed God's will. “Thus, by abandoning pragmatist methods in his personal politics, Wilson missed his greatest opportunity to infuse them into the law and life of nations." 27 Refusing to compromise with Republican senators, he sacrificed the promise of pragmatic Wilsonianism, as Throntveit understood it.

But if the president did not engage in common counsel during the peacemaking after World War I, did he ever really adopt the pragmatist ideas that Throntveit attributed to his internationalism? Power Without Victory did not give a convincing answer to this question. Wilson's supposed abandonment of pragmatism during the peacemaking was not the only time he failed to keep his apparent promises. He was skillful at convincing others that he accepted their ideas-including American peace activists seeking to end the war, African Americans seeking racial democracy in Jim Crow America, and anticolonial nationalists seeking selfdetermination in the non-Western world-until they were disillusioned by his practices. ${ }^{28}$

Historians and political scientists have recognized that the world has not reached the "end of history" during the past century. Most of us have not shared Wilson's belief in the politics of inevitability. Viewing contingency in history, we acknowledged the difficulty of implementing Wilsonianism, however understood, in international politics. In view of Wilson's inability to create a new world order in the peacemaking after World War I, some scholars originated and others later affirmed realism as an alternative to his liberal internationalism. Even some liberal internationalists incorporated realist insights into their interpretations. Scholars who have most admired Wilson generally admitted that he was at least partly responsible for his failure. Yet 
they continued to hold out the hope that his original vision of Wilsonianism might be revived as a guide to international relations in place of the neo-Wilsonianism that so obviously contributed to catastrophic consequences in the early twenty-first century. Unfortunately, ideas associated with his legacy helped the Bush Doctrine justify the unwinnable wars that continued throughout the presidencies of George W. Bush and Barack Obama. The failure of military intervention to promote human rights and liberal democracy in the Middle East also undermined the progressive belief in the politics of inevitability and helped usher in the politics of eternity, seen most clearly in Donald J. Trump's presidency. Imperial crusades abroad produced illiberal outcomes at home that threatened freedom and democracy in the United States. Let us hope that we can adopt the politics of responsibility. This will require us to confront our history and avoid the false promise of a new world order, whether identified with Wilson's Wilsonianism or otherwise. 
1. Timothy Snyder, The Road to Unfreedom: Russia, Europe, America (New York: Tim Duggan Books, 2018), 7-8.

2. Snyder, Road to Unfreedom, 8-9, 19, 35, 112, 281.

3. John J. Mearsheimer, The Great Delusion: Liberal Dreams and International Realities (New Haven, CT: Yale University Press, 2018), 56-61, 189, 195.

4. Francis Fukuyama, The End of History and the Last Man (New York: Free Press,1992), 45.

5. Mearsheimer, Great Delusion, 219-20.

6. Stephen M. Walt, The Hell of Good Intentions: America's Foreign Policy Elite and the Decline of U.S. Primacy (New York: Farrar, Straus and Giroux, 2018), 168-69.

7. John J. Mearsheimer, The Tragedy of Great Power Politics (New York: W. W. Norton, 2001), 210.

8. Mearsheimer, Tragedy of Great Power Politics, 14, 234, 361.

9. Richard Fox, Reinhold Niebuhr: A Biography (New York: Pantheon Books, 1985); Ronald

Steel, Walter Lippmann and the American Century (Boston: Little, Brown and Company, 1980);

John Lewis Gaddis, George F. Kennan: An American Life (New York: Penguin Books, 2011);

Christoph Frei, Hans J. Morgenthau: An Intellectual Biography (Baton Rouge, LA: LSU Press, 2001).

10. Norman A. Graebner, A Twentieth-Century Odyssey: Memoir of a Life in Academe (Claremont, CA: Regina Books, 2001), 102-112, 129-52.

11. Lloyd E. Ambrosius, Woodrow Wilson and the American Diplomatic Tradition (New York: Cambridge University Press, 1987); Lloyd E. Ambrosius, Woodrow Wilson and American Internationalism (New York: Cambridge University Press, 2017).

12. Lloyd E. Ambrosius, "Woodrow Wilson and World War I," Passport: The Society for Historians Review (April 2017), 48: 31-39. For different perspectives, see John Milton Cooper, Jr., Woodrow Wilson: A Biography (New York: Alfred A. Knopf, 2009) and Patricia O'Toole, The Moralist: Woodrow Wilson and the World He Made (New York: Simon and Schuster, 2018). They downplayed the religious and racial factors in the president's ideas and politics, as did most other pro-Wilson scholars.

13. Tony Smith, America's Mission: The United States and the Worldwide Struggle for Democracy in the Twentieth Century (Princeton, NJ: Princeton University Press, 1994), xv, 3, 30, 32, 345 .

14. Tony Smith, A Pact with the Devil: Washington's Bid for World Supremacy and the Betrayal of the American Promise (New York: Routledge, 2007), ix, xxiv, xxxviii, 52. For my realist critique in 2006 of the Bush Doctrine and its advocates, see Ambrosius, Woodrow Wilson and American Internationalism, 192-229.

15. Smith, Pact with the Devil, 98, 193.

16. Lloyd E. Ambrosius, "World War I and the Paradox of Wilsonianism," Journal of the Gilded Age and Progressive Era (January 2018), 17: 5-22; Christopher Capozzola, Uncle Sam Wants You: World War I and the Making of the Modern American Citizen (New York: Oxford University Press, 2010).

17. Francis Fukuyama, America at the Crossroads: Democracy, Power, and the Neoconservative Legacy (New Haven, CT: Yale University Press, 2006), 9.

18. Tony Smith, Why Wilson Matters: The Origin of American Liberal Internationalism and Its Crisis Today (Princeton, NJ: Princeton University Press, 2017), xvii-xviii, 5, 35, 75-76, 91, 13043, 219, 229. 
19. G. John Ikenberry, Thomas J. Knock, Anne-Marie Slaughter, and Tony Smith, The Crisis of American Foreign Policy: Wilsonianism in the Twenty-first Century (Princeton, NJ: Princeton University Press, 2009), 13-14, 21.

20. G. John Ikenberry, Liberal Leviathan: The Origins, Crisis, and Transformation of the American World Order (Princeton, NJ: Princeton University Press, 2011), xi, 165-66.

21. G. John Ikenberry, After Victory: Institutions, Strategic Restraint, and the Rebuilding of Order after Major Wars (Princeton, NJ: Princeton University Press, 2001).

22. Thomas J. Knock, To End All Wars: Woodrow Wilson and the Quest for a New World Order (New York: Oxford University Press, 1992), 57.

23. Ikenberry, Knock, Slaughter, and Smith, Crisis of American Foreign Policy, 28, 31.

24. Ikenberry, Knock, Slaughter, and Smith, Crisis of American Foreign Policy, 54-55, 57.

25. Ikenberry, Knock, Slaughter, and Smith, Crisis of American Foreign Policy, 91-92, 109, 111, 117.

26. Trygve Throntveit, Power Without Victory: Woodrow Wilson and the American

Internationalist Experiment (Chicago: University of Chicago Press, 2017), 5, 12, 17, 31, 125.

27. Throntveit, Power Without Victory, 241, 244, 285, 288.

28. Michael Kazin, War Against War: The American Fight for Peace (New York: Simon and Schuster, 2017); Ambrosius, Woodrow Wilson and American Internationalism, 63-93; Erez Manela, The Wilsonian Moment: Self-Determination and the International Origins of Anticolonial Nationalism (New York: Oxford University Press, 2007). 